\title{
Expression of lectin and defensin genes in Mironovskaya 808 and Roazon wheat cultivars infected with Pseudocercosporella herpotrichoides
}

\author{
V. N. Belava, S. B. Zeleniy ${ }^{1}$, O. O. Panyuta, N. Yu. Taran, P. V. Pogribniy ${ }^{1}$ \\ Taras Shevchenko National University of Kyiv \\ 64, Volodymyrska Str., Kyiv, Ukraine, 01033 \\ ${ }^{1}$ R. E. Kavetsky Institute of Experimental Pathology, Oncology, and Radiobiology, NAS of Ukraine \\ 45, Vasylkivska Str., Kyiv, Ukraine, 03022
}

v897@ukr.net

\begin{abstract}
Aim. The dynamics of expression of protective proteins (lectin and defensin) genes of different genotypes of the winter wheat, affected by P. herpotrichoides, was investigated. Methods. RT-PCR was used for gene expression analysis. Results. We established that the lectin mRNA content in control and infecting plants of the resistant cultivar is considerably higher than in the susceptible one; the character of defensin $m R N A$ accumulation in the investigated cultivars, control and infecting plants, does not change. Conclusion. The spare pool of lectin mRNA in the resistant cultivar is more substantial, than in the susceptible one, that is, possibly, one of the factors of the plant resistance. Inability to support constantly a high level of the protective genes expression seems to influence negatively on the cultivar resistance.
\end{abstract}

Keywords: lectin, defensin, $m R N A$, eyespot, wheat.

Introduction. Plant-pathogen biochemical interactions under the infection process demonstrate complicated regulatory linkage between these two organisms. The investigation of these interactions on the levels, ranging from the organism to a cell, testifies to the activation of different mechanisms of pathogen attack and plant defence, depending on the stage of development of the disease. The resistance of plants to pathogens is determined by complicated interdependent systems, which are genetically controlled. Antimicrobial compounds have the most

(C) Institute of Molecular Biology and Genetics NAS of Ukraine, 2010 complicated mechanisms of defence, serving to recognize and eliminate specific kinds of pathogenic cells attack.

Lectins, low-molecular proteins, are primary substances, responsible for the process of recognizing a foreign agent, its binding, prevention or slowing down the infection process. They also participate in the formation of plant immunity as a primary link of elicitor-induced launch of plant cell signalling systems. The hypotheses on the participation of lectins in plant defence from pathogenic agents are proven by the data on the capability of lectins to have specific interaction with the surface of bacterial cells, of fungal spores and 
hyphae [1]; it results in incompatible or compatible interaction of organisms which is revealed in induction or absence of plants defence reaction to the pathogen attack.

On the other hand, inherent immunity is conditioned by the presence (or capability of quick synthesis) of a certain number of antimicrobial compounds and their activation at the exogenous elicitor action [2]. One of the classes of such compounds is plant defensins - minor peptides, micromolar concentrations [3] of which demonstrate antimicrobial activity against a wide spectrum of phytopathogenic fungi as well as agents of human diseases [4, 5]. Besides, they launch signalling cascades [6] and cause morphological changes in fungal hyphae $[7,8]$.

Experimental data bring evidence to the expression of plant defensins genes in response to fungal attack which increases plants resistance to pathogenic agents [9].

Since the active reactions to the attack of pathogenic agents are usually connected with the change in expression of genes, coding pathogen-induced proteins [10], the aim of this work was to study the dynamics of lectin and defensin genes expression in the formation of immune response of winter wheat cultivars (Triticum aestivum L.), differing in their level of resistance, which were affected by eyespot agent ( $P$. herpotrichoides (Fron) Deighton) at early stages of ontogenesis.

Materials and Methods. The objects of study were winter wheat ( $T$. aestivum L.) seedlings of susceptible to eyespotcultivar Mironivska 80 (Ukrainian selection), and seedlings of comparatively resistant cultivar Roazon (French selection), selected on the basis of literature data and resistance screening of cultivars, previously performed [11]. Conidia suspension with the initial titre $(5-7) \cdot 10^{4}$ conidia $/ \mathrm{ml}$ [11] of highly virulent strain $543 \quad 7 / 1$ P. herpotrichoides (Fron) Deighton (synonym Cercosporella herpotrichoides, teleomorph Tapesia yallundae (Wallwork \& Spooner), synonym Oculimacula yallundae [12]) was used for infecting. Fungi granted by the laboratory of agricultural plants immunity to diseases, Institute of Plant Protection, UAAS.
The expression of lectin gene $W G A-B$ (B-lectin $T a G L L c)$ and defensin gene ( $\operatorname{Tad} 1)$ was determined using RT-PCR ( reverse transcription polymerase chain reaction) [13]. The initial level of transcripts was determined 24 hours after the start of first watering of studied seeds - at the moment of inoculation with conidia suspension. The following samples were selected every 1.5 hour (for 6 hours). The seedlings were fixed in liquid nitrogen and total RNA was isolated by the method of acid-phenol extraction according to the standard scheme [14]. The data on nucleotide sequences of gene sequences of lectin and defensin of T. aestivum were obtained from nucleotide database of the National Center for Biotechnology Information US (PubMed). Primers were selected using Primer detection program (the most suitable primers for lectin were 5'-gcatgagcatctt-cagctca-3', 5'-ctgtccaagacgacggacta-3'; for defensin 5'-ttccgtttcctttacgtgct-3', 5'-atcagcaggtttgttggaac-3'). Oligonucleotide primers (Biolabtech company) were used. The calculation of relative amount of gel pictures was conducted using TotalLab program. The intensity of gel picture staining was calculated as a number of pixels, the data were registered in conventional units (c.u.).

To make sure that mRNA[s] of $P$. herpotrichoides do not influence the results of RT-PCR of mRNA expression of plant lectin and defensin genes during infecting, we conducted separate RT-PCR of mRNA of studied genes of $T$. aestivum fungal mycelium and conidia. The absence of PCR products with cDNA of lectin and defensin of fungus may be explained by the fact that primers, selected for amino acid sequences of plant nucleic acids, do not launch corresponding synthesis with fungus cDNA.

The results were statistically processed, they were considered reliable at 5\% error using Student's criteria.

Results and Discussion. According to the data of Lepekhin et al. [15], a considerable number of lectins are synthesized during seed germination at early stages of seedlings development. Besides, the application of mRNA transcription inhibitor allowed to prove the existence of a pool of spare forms of lectin mRNA in wheat germs [16] which promotes quick increase in the lectin activity due to the synthesis of protein de novo.

Our research on the expression of lectin gene in healthy seedlings of Mironivska 808 cultivar, sensitive 


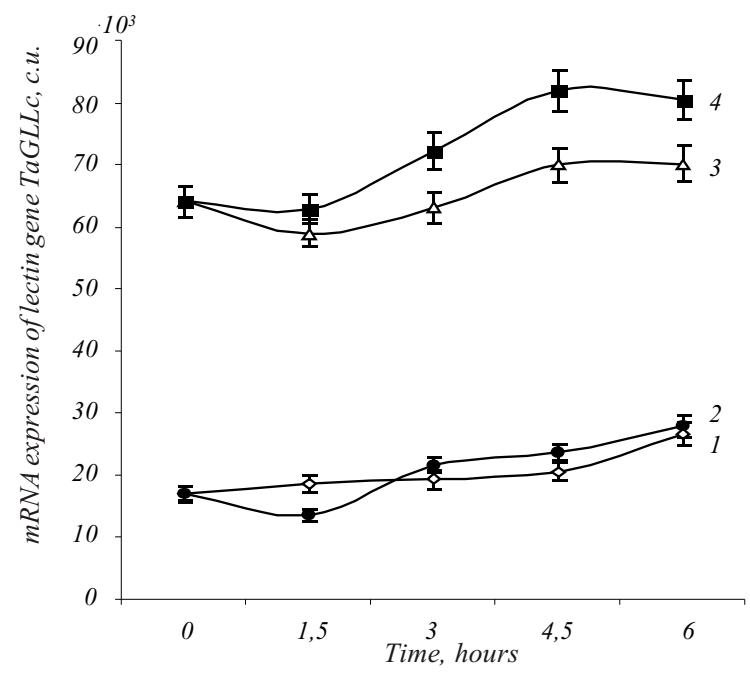

Fig. 1 The change in the mRNA expression of lectin gene TaGLLC in $T$. aestivum seedlings during infecting with $P$. herpotrichoides according to the results of RT-PCR: 1,2-Mironivska 808 - control and infecting, respectively; 3, 4-Roazon - control and infecting, respectively

to eyespot, demonstrated gradual accumulation of mRNA during 6 hours of the experiment (Fig.1). It may be explained by the fact that the expression of protective proteins genes occurs not only in conditions of pathogenesis or under the influence of elicitors, but also in the course of normal ontogenesis of plants - seeds germination, flourishing, and tissues ageing. The induction of such stress molecules as protective proteins, which are rather specific towards phytopathogens, is considered to be the launch of a mechanism of plants pre-adaptation to possible infecting, as this stress factor considerably diminishes life potential of plants and makes them more sensitive to pathogen aggression [17].

There is a completely different picture in case of infecting. At early stages of infection in the conditions of development of defence response, there is an increase in the activity of a series of enzymes in plants, with the synthesis of mRNA and proteins de novo [18]. The fungi suppressors, inhibiting the resistance of plants to infecting, are known to inhibit protective biosynthetic activity of damaged tissues [19]. Immunosuppression is an inherent feature of parasitism, and immunosuppressors are natural antagonists of elicitors which induce sensitivity to diseases in plant tissues. The research of Medvedeva et al. [19] proves that the activity of suppressors is aimed at inhibition of new proteins synthesis. It determines the activation of tissues, induced by recognition of pathogen plant.

There are grounds for logical assumption that this inhibition of new formation of protective proteins by fungi suppressors also occurs either at the transcription level proper, or at the level of signalling systems, activating transcription. This may explain considerable decrease in the number of mRNA in infected seedlings of susceptible Mironivska 808 cultivar 1.5 hour after the start of infecting. In our opinion, subsequent accumulation of mRNA is conditioned by the launch of other signalling systems, activating defence mechanisms, namely, overcoming of suppressor effect of a fungus by the plant.

The research of dynamics of lectin mRNA number in healthy seedlings of resistant Roazon cultivar revealed insignificant fluctuation (not more than $8 \%$ ) of this index, which is explained by active growth processes and biosynthesis of a large amount of other proteins. Meanwhile, there is a tendency to gradual accumulation of mRNA.

The study on the mRNA dynamics in infected seedlings of the resistant cultivar demonstrated insignificant decrease in mRNA content 1.5 hours later. Probably, it should not be considered as the inhibiting effect of fungal suppressors, i.e. it is possible that first visible changes in the level of lectin mRNA are registered 3 hours after the start of infecting. By that time the amount of lectin mRNA is $112 \%$ compared to the level at the infecting moment, and 4.5 hours later it is as high as $128 \%$. Therefore, the expression of lectin gene and accumulation of mRNA occur in response to the effect of pathogen.

The comparison of results on lectin mRNA accumulation in wheat tissues of both sensitive and comparatively resistant cultivars shows that this index for Roazon cultivar is much higher than that for Mironivska 808 cultivar both in the control and in case of infecting: it is 2.6-3.8 and 2.9-4.7 times higher in the control and during infection, respectively. It means that a spare pool of lectin mRNA of the resistant cultivar is much more substantial than that of the sensitive one and can be one of the factors of cultivar resistance. 


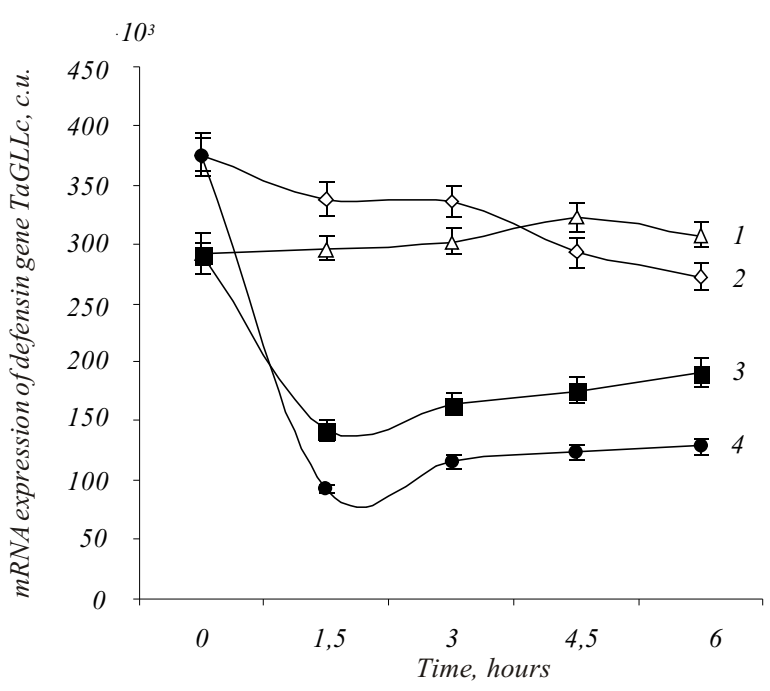

Fig. 2 The change in the mRNA expression of defensin gene Tad1 in $T$. aestivum seedlings during infecting with $P$. herpotrichoides according to the results of RT-PCR: 2, 4-Mironivska 808 - control and infecting, respectively; 1,3-Roazon - control and infecting, respectively

The study on the dynamics of the expression of defensin gene in the seedlings of sensitive and comparatively resistant wheat cultivars during infecting with $P$. herpotrichoides revealed a different picture. During the experiment there was decrease in the amount of defensin mRNA in control seedlings of the sensitive cultivar Mironivska 808, which is in agreement with the data on the presence of DNA-derivative transcripts in maturing and mature seeds and on their almost complete absence in healthy non-infected leaves [9] (Fig.2).

A considerable decrease (4-fold) in the amount of defensin mRNA is observed in the seedlings of the sensitive cultivar just 1.5 hours after the moment of infecting, then it gradually increases. But even 6 hours after infecting it is 3 times lower than the initial value. Probably, it may be explained by the an inhibiting effect of immunosuppressors of pathogen on the expression of defensin genes.

The analysis of the defensin mRNA content change in the seedlings of the resistant cultivar Roazon demonstrated that there was no decrease in the number of transcripts in the control during the experiment; on the contrary, insignificant increase was observed. In our opinion it is in agreement with the data of Terras et al. [9] on the evacuation of defensins into the environment during germination of seeds and formation of its own micromedium, in which fungi growth is inhibited. It is possible that pre-adaptation synthesis of protecting protein and formation of micromedium in the seedlings tissues of the resistant cultivar is the reason for both high level of defensin genes expression, and, probably, formation of a spare mRNA pool.

During infecting there is a double decrease in the amount of mRNA in the seedlings of resistant cultivar, but the rates of restoring mRNA level are twice higher than those for the sensitive cultivar. Probably, the rate of restoring capability to express genes of protective proteins is one of indices determining the degree of cultivar resistance.

Comparison of the results on accumulation of defensin mRNA in wheat tissues of the sensitive and comparatively resistant cultivars testifies to the fact that the character of changes in this index is the same for cultivars, different in their resistance, in both control and infection. However, the boundaries and, therefore, fluctuations of absolute values for the sensitive cultivar are broader than those for the resistant one. In other words, in this case the inability to support constantly a high level of the protective genes expression seems to have negative impact on cultivar resistance.

Conclusions. The dynamics of expression of lectin and defensin genes in seedlings of winter wheat cultivars, different in their level of resistance, which were infected with $P$. herpotrichoides, evidenced that the stress effect of phytopathogen changes the content and ratio of studied transcripts of antimicrobial substances, lectins and defensins, genes in plant tissues. The increase in expression of lectin mRNA was revealed in non-infected seedlings of studied cultivars. This index is considerably higher in tissues of resistant cultivar seedlings than that for the seedlings of the sensitive cultivar both in control and during infection. It means that a spare pool of lectin mRNA is much more substantial for the resistant cultivar as compared with sensitive one, which may be one of the factors of cultivar resistance.

The study on the dynamics of mRNA expression of defensin gene in non-infected seedlings revealed that this index decreases for the sensitive cultivar, while it gets somewhat higher for the resistant one. During 
infection the character of changes in this index is stable for the cultivars, different in their resistance. However, the boundaries and, therefore, fluctuations of absolute values for the sensitive cultivar are broader than those for the comparatively resistant one. In this case the inability to support constantly a high level of the protective genes expression seems to have negative impact on cultivar resistance.

The changes and differences in mRNA content of protective minor proteins of lectin and defensin in tissues of wheat cultivars, different in their resistance, which were revealed during infecting with eyespot causative agent, characterize these proteins as a vital constituent in the formation of adaptive reactions to pathogenesis. The inhibiting effect of pathogen immunosuppressors on the expression of protective proteins genes determines the degree of induced resistance of winter wheat plants to the pathogen depending on the level of accumulation of mRNA of minor protective proteins - lectins and defensins.

\section{В. Н. Белава, С. Б. Зеленый, О. А. Панюта, Н. Ю. Таран, П. В. Погребной}

Экспрессия генов лектина и дефенсина у сортов пшеницы Мироновская 808 и Roazon при инфицировании Pseudocercosporella herpotrichoides

Резюме

Цель. Исследовать динамику экспрессии генов защитных белков (лектина и дефенсина) разных генотипов озимой пшеницы, nораженных $P$. herpotrichoides. Mетоды. Экспрессию генов определяли при помощи реакции RT-PCR. Результаты. Содержание мРНК лектина в контроле и при инфицировании $P$. herpotrichoides y относительно резистентного сорта (Roazon) значительно выше, чем у восприимчивого (Мироновская 808). Характер содержания мРНК дефенсина у исследуемых сортов в контроле и при инфицировании не меняется, но границы колебаний абсолютных значений у восприимчивого сорта шире. Выводы. Запасной пул мРНК лектина у резистентного сорта гораздо массивней, чем у восприимчивого, что, вероятно, является одной из составляющих устойчивости сорта. Неспособность поддерживать постоянно высокий уровень экспрессии генов защитных соединений негативно влияет на устойчивость сорта.

Ключевые слова: лектины, дефенсины, мРНК, иеркоспореллез, пшеница.
В. Н. Белава, С. Б. Зелений, О. О. Панюта, Н. Ю. Таран, П. В. Погрібний

Експресія генів лектину та дефенсину у сортів пшениці Миронівська 808 та Roazon за інфікування Pseudocercosporella herpotrichoides

Резюме

Мета. Дослідити динаміку експресї генів захисних білків (лектину та дефенсину) різних генотипів озимої пшениці, уражених P. herpotrichoides. Методи. Експресію генів визначали за допомогою RT-PCR. Результати. Вміст мРНК лектину у контролі та за інфікування P. herpotrichoides у відносно резистентного (Roazon) сорту вищий, ніж у сприйнятливого (Миронівська 808). Характер накопичення мРНК дефенсину у досліджуваних сортів у контролі та за інфікування не змінюється, але межі коливання абсолютних значень у сприйнятливого сорту ширші. Висновки. Запасний пул мРНК лектину у резистентного сорту набагато масивніший порівняно зі сприйнятливим, шьо, можливо, є однією із складових стійкості сорту. Нездатність підтримувати постійно високий рівень експресії генів захисних сполук негативно впливає на стійкість сорту.

Ключові слова: лектини, дефенсини, мРНК, иеркоспорельоз, пшениия.

\section{REFERENCES}

1. Etzler M. E. Are lectins involved in plant - fungus interactions? // Phytopathology.-1981.-71, N 7.-P. 744-746.

2. Boman H. G. Peptide antibiotics and their role in innate immunity // Annu. Rev. Immunol.-1995.-13.-P. 61-92.

3. Lay F. T., Anderson M. A. Defensins - components of the innate immune system in plants // Curr. Protein Pept. Sci.2005.-N 6.-P. 85-101.

4. Terras F. R., Schoofs H. M., De Bolle M. F., Van Leuven F., Rees S. B., Vanderleyden J., Cammue B. P., Broekaert W. F. Analysis of two novel classes of plant antifungal proteins from radish (Raphanus sativus L.) seeds // J. Biol. Chem.1992.-267, N 22.-P. 15301-15309.

5. Butaye K. M., Goderis I. J., Wouters P. F., Pues J. M., Delaure S. L., Broekaert W. F., Depicker A., Cammus B. P., de Bolle M. F. Stable high-level transgene expression in Arabidopsis thaliana using gene silencing mutants and matrix attachment regions // Plant J.-2004.-39, N 3.-P. 440-449.

6. Aerts A. M., Francois I. E., Bammens L., Cammus B. P., Smets B., Winderickx J., Accardo S., De Vos D. E, Thevissen $K$. The antifungal activity of RsAFP2, a plant defensin from Raphanus sativus, involves the induction of reactive oxygen species in Candida albicans // FEBS Lett.-2006.-580, N 7.P. 1903-1907.

7. Kovalyova V. A., Gout R. T., Gout I. T. Production of Scots pine recombinant 1 and its antifungal activity // Biopolym. cell.-2008.-24, N 5.-P. 377-384.

8. Kovalyova V. A., Gout I. T., Gout R. T. Characterization of defensin-like proteims from Scots pine seedlings // Biopolym. cell.-2006.-22, N 2.-P. 126-131. 
9. Terras F. R., Eggermont K., Kovaleva V. Raikhel N. V., Osborn R. W., Kester A., Rees S. B., Torrekens S., van Leuven F., Vanderleyden J., Cammue B. P. A., Broekaert W. F. Small cysteine-rich antifungal proteins from radish: their role in host defense // Plant Cell.-1995.-7, N 5.-P. 573-588.

10. Tarchevsky I. A. Pathogen-Induced Plant Proteins // Appl. Biochem. and Microbiol.-2001.-37, N 5.-P. 441-455.

11. Belava $V$., Panyuta O., Taran N. Model system of infection and level of winter wheat (Triticum aestivum L.) resistance estimation to eyespot agent (Pseudocercosporella herpotrichoides (Fron) Deighton) // Karantyn i Zakhyst Roslyn.2008.-N 7.-P. 25-28.

12. Wallwork H., Spooner B. Tapesia yallundae - the teleomorph of Pseudocercosporella herpotrichoides // Transact. Brit. Mycol. Soc.-1988.-91, N 44.-P. 703-705.

13. Bartlett J., Stirling D. PCR Protocols, $2^{\text {nd }}$ ed.-Totowa: Humana Press, 2003.-556 p.

14. Maniatis T., Fritsch E. F., SambrookJ. Molecular cloning: a laboratory manual.-New York: Cold Spring Harbor Lab. press, 1982.-545 p.
15. Lepekhin E. A., Yalovoi A. I., Rybak V. I. Activity and specificity carbohydrates in lectins of germinating maize grains // Russ. J. Plant Physiol.-1986.-33, N 2.-P. 390-394.

16. Peumans W. J., Stinissen H. M., Carlier A. A genetic basis for the origin of six different isolectins in hexaploid wheat // Planta.-1982.-154, N 6.-P. 562-567.

17. Shakirova $F$. M. Nonspecific resistance to stressful factors and its regulation.-Ufa: Gilem, 2001.-160 p.

18. Yamamoto H., Tani T., Naito N. Changes in protein contents of oat leaves during the resistant reaction against Puccinia coronata avenae // Phytopathology.-1975.-82, N 2.-P. 138145.

19. Medvedeva T. E., Chalenko G. I., Vasyukova N. I., Ozeretskovskaya $O$. L. Influence of suppressor of the potato late blight causal agent on wounding reparation of potato tubers // Dokl. Akad. Nauk SSSR.-1985.-280, N 3.-P. 764-767.

UDC 581.1:632.4:577.113 Received 10.02.09 